\title{
Synchronous Bilateral Male Breast Cancer: A Rare Case Report
}

\author{
Senkron Bilateral Erkek Meme Kanseri: Nadir Bir Olgu \\ • Muzaffer Akıncı, • Zehra Keklikkıran, • Mürşit Dinçer \\ Haseki Training and Research Hospital, Clinic of General Surgery, Istanbul, Turkey
}

Abstract

Male breast cancer accounts for less than $1 \%$ of all breast carcinomas and 0.17 to $-1.5 \%$ of all cancers seen in men. The incidence of synchronous bilateral male breast cancer has been reported to be $1.5 \%-2 \%$ of all male breast cancers. Although it can affect men of any age, the median age at diagnosis is 60-70 years. Herein, we report a case of bilateral/synchronous male breast cancer.

Keywords: Male breast cancer, invasive ductal carcinoma, synchronous tumor

\begin{abstract}
Erkek meme kanseri tüm meme kanseri olgularının \%1'inden daha azını oluşturur ve erkeklerde görülen tüm kanserlerin \%0,17 -\%1,5'ini oluşturur. İnsidansı tüm erkek meme kanserlerinin \%1.5 ila \%2'sidir. Her yaştan erkeği etkileyebilmesine rağmen tanıdaki medyan yaşı 60-70 yıldır. Bu çalışmada bilateral/senkron erkek meme kanseri olgusu sunuldu.
\end{abstract}

Anahtar Sözcükler: Erkek meme kanseri, invaziv duktal karsinom, senkron tümör

His daughter had breast cancer and she was operated 8 months ago. The patient had no history of chest pain, weight loss, dypnea, night sweats or cough. There was no history of bone pain, abdominal pain/swelling or low back pain. He had no history of gynecomastia, solid organ tumor or hormone therapy. He was not a heavy drinker and quit smoking 6 years ago. His body mass index was 31.25 (height $165 \mathrm{~cm}$; body weight $85 \mathrm{~kg}$ ). The right nipple was retracted and there was a protuberant, red, solid mass in the lateral side of the left breast (Figure 1). His physical examination showed a $2.5-\mathrm{cm}$ palpable mass just under the right nipple and a $5.5-\mathrm{cm}$ mass in the lateral side of the left breast. Left axillary lymph nodes were palpable. There was no other remarkable pathological finding on his physical examination. The patient's hormone profiles were normal. Level of CA 15-3 was slightly increased (53.4 $\mathrm{U} / \mathrm{mL}$; normal range $=0-31.3 \mathrm{U} / \mathrm{mL}$ ). He refused genetic analyses for BRCA1/2 genes. Radiologic examination, breast ultrasonography and breast magnetic resonance imaging showed masses in the subareolar area of both breasts (Figures 2). In addition, chest radiography and
Address for Correspondence/Yazışma Adresi: Mürşit Dinçer, Haseki Training and Research Hospital, Clinic of General Surgery, İstanbul, Turkey

Phone: +90 5446422820 E-mail: drmursitdincer@gmail.com ORCID: orcid.org/0000-0002-1930-0383 Received/Geliş Tarihi: 31 March 2019 Accepted/Kabul Tarihi: 26 May 2019

This study was presented at $21^{\text {st }}$ National Congress of Surgery as an oral presentation in 2018.
${ }^{\circ}$ Copyright 2019 by The Medical Bulletin of istanbul Haseki Training and Research Hospital The Medical Bulletin of Haseki published by Galenos Yayınevi. •Telif Hakkı 2019 istanbul Haseki Eğitim ve Araştırma Hastanesi Haseki Tıp Bülteni, Galenos Yayınevi tarafından yayınlanmıștır. 
liver ultrasonography showed no evidence of metastatic disease. Preoperative F-18-fluorodeoxyglucose positron emission tomography/computed tomography revealed bilateral uptake in the subareolar area of SUV $V_{\max } 11.0$ in the left breast with cutaneous invasion, and mild uptake in both axillae. Core-needle biopsy revealed invasive ductal carcinoma in the right breast and papillary neoplasia with in situ carcinoma in the left breast. There was no pathology in the fine needle aspiration cytology of the left axillary lymph node. Left modified radical mastectomy and right simple mastectomy and right sentinel lymph node biopsy (negative) were performed. Histopathological examination revealed invasive ductal carcinoma in the right breast (maximum diameter $-2.5 \mathrm{~cm}$ ), and intracystic papillary carcinoma in the left breast (maximum diameter $-5.5 \mathrm{~cm}$ ). Invasive ductal carcinoma in the right breast consisted mainly of micropapillary components and tumor cells and intracystic papillary carcinoma in the left breast. Tumor, nodes, metastases classification was consistent with stage IIla. There was no evidence of tumor invasion into the pectoralis major muscle on either side. There was no evidence of tumor invasion of the skin in both breasts. Immunohistochemical staining of the left breast tumor revealed negative estrogen receptor $3+/ 3(>95 \%)$, progesterone receptor 3+/3 (95\%) and c-erbB-2. Adjuvant hormone therapy and chemotherapy were planned for the patient.

\section{Discussion}

Bilateral $M B C$ is very rare clinical entity with the reported incidence of $1.5 \%$ to $2 \%$ of all MBCs. The average age at diagnosis is 60-70 years. Tumor size and number of axillary nodes involved are the main prognostic factors. These factors guide the treatment choice. Locoregional approaches include surgery and radiotherapy (RT), depending upon the initial clinical presentation. The choice of systemic treatment between hormonal

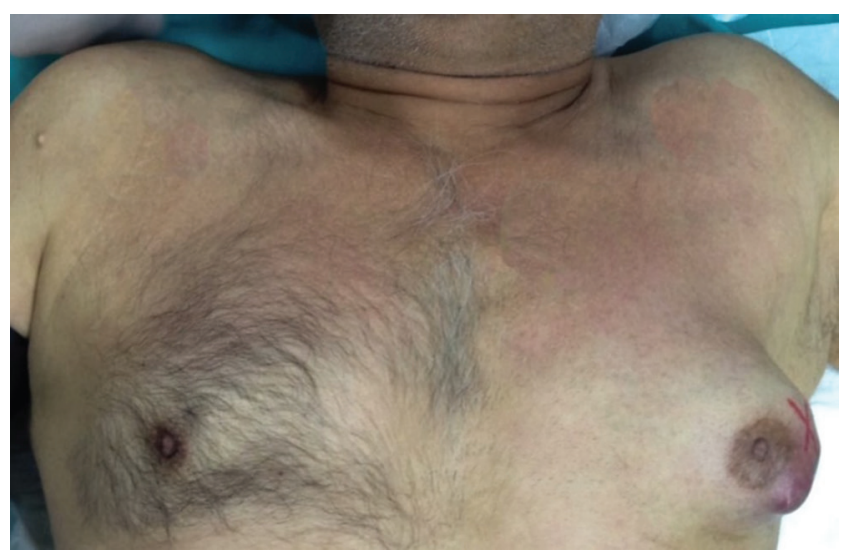

Figure 1. Patient aged 72 years with synchronous bilateral breast cancer and or chemotherapy (CT) should depend upon the FBC management guidelines. It should be kept in mind that there are high rates of age-related comorbidities of CT (1). Bilateral, simultaneous presentation is extremely rare and is $1-2 \%$ of the total number of patients with breast cancer (2-6). Bilateral breast cancer is defined as the presence of an independent primary malignant tumor in each mammary gland; the term "synchronized" refers to the presence of primary tumors diagnosed simultaneously in both breasts $(2,7,8)$.

Metachronous bilateral involvement is more common than synchronous bilateral involvement $(6,7)$. In the literature, there are case reports about synchronous bilateral MBC associated with male potential

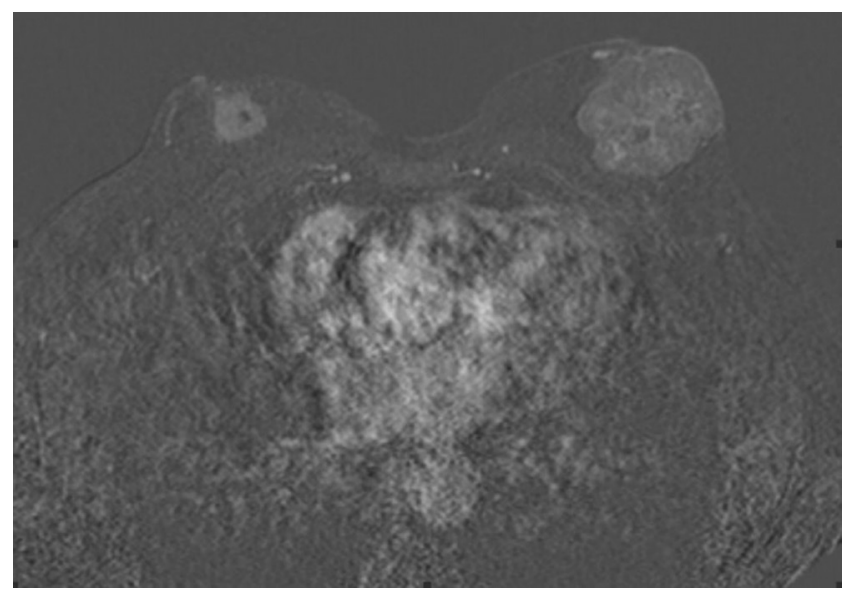

Figure 2. MRG of 90-sec post-contrast sequence showed masses in the subareolar area of both breasts. A large heterogeneous mass with mixed enhancement pattern is present in the left subareolar corresponding to malignancy. The margins of the mass are partly smooth defined but seems skin involvement with the mass measuring approximately $5.5 \mathrm{~cm}$. The other mass, 2.5 $\mathrm{cm}$ in size with poor defined margin, is under the right nipple and caused right nipple retraction.

Magnetic resonance imaging (MRI) of 90-sec post-contrasted T1 FSPGR sequence (lateral view of right breast, Case 5). Palpable lesion on the lower outer quadrant $(4 \mathrm{~cm})$ and suspicious axillary nodes previously were seen on mammography and ultrasonography (US) (invasive ductal carcinoma on core biopsy of the breast lesion; fine needle aspiration positive for malignancy on lymph node). These patients were primarily planned to go through neoadjuvant chemotherapy followed by breastconservation surgery in case of a sufficient clinical response. MRI has showed multicentricity on upper outer quadrant, changing surgical plan to mastectomy MRI of $90-\mathrm{sec}$ post-contrasted T1 FSPGR sequence (lateral view of right breast, Case 5). Palpable lesion on the lower outer quadrant $(4 \mathrm{~cm})$ and suspicious axillary nodes previously were seen on mammography and US (invasive ductal carcinoma on core biopsy of the breast lesion; fine needle aspiration positive for malignancy on lymph node). These patients were primarily planned to go through neoadjuvant chemotherapy followed by breast-conservation surgery in case of a sufficient clinical response. MRI has showed multicentricity on upper outer quadrant, changing surgical plan to mastectomy 
hypogonadism, hormonal therapy due to prostate cancer, hyperprolactinemia, long standing gynecomastia, and chromosomal abnormality (XXY or $45, X / 46, X Y$ mosaic karyotype) (9-11). The most common histological type in men is invasive ductal carcinoma (85-90\%) as in women. Invasive papillary carcinoma is twice as common in men as in women $(2-4 \%$ vs $1 \%)(12,13)$. Many different risk factors have been identified for male breast cancer, including familial and genetic factors (BRCA2), Klinefelter syndrome $(47, X X Y)$, radiation exposure, hormonal imbalance, obesity, and testicular disease (undescended testis, orchitis, orchiectomy) $(14,15)$. It has been reported that mutations of $B R C A 2$ gene are more frequent in males with breast cancer and the estimated mutation carrier frequencies varied from $4 \%$ to $40 \%$ (16). BRCA2 MBC is more likely to test positive for hormone receptors, but is less likely to show c-erbB-2 over-expression compared to FBC (17). There is no data comparing $M B C$ results in relation to the differences between unilateral and bilateral cases. The treatment of MBC is based on local and regional control of the disease with surgical and radiation therapy, and systemic control with hormone therapy and chemotherapy (18).

\section{Conclusion}

Due to the rarity of bilateral $\mathrm{MBC}$, men often ignore the importance of examining their breasts. Since male breast cancer can be overlooked because its rarity, we wanted to emphasize the importance of breast cancer in men.

\section{Authorship Contributions}

Concept: M.A. Design: M.A. Data Collection or Processing: M.D. Analysis or Interpretation: M.D. Literature Search: Z.Z.K. Writing: M.A.

Conflict of Interest: No conflict of interest was declared by the authors.

Financial Disclosure: The authors declared that this study received no financial support.

\section{References}

1. Ottini L, Palli D, Rizzo S, et al. Male breast cancer. Crit Rev Oncol Hematol 2010;73:141-55.

2. Ipiña JM, Gonzalez E, Noelia C, et al. Cáncer de mama bilateral. Rev Argent Mastología 2007;26:273-80.

3. García-Mejido JA, Delgado-Jiménez C, Gutiérrez-Palomino L, et al. Synchronous bilateral breast cancer in a male. Cir Cir 2013;81:225-7.
4. Sosnovskikh I, Naninato P, Gatti G, et al. Synchronous bilateral breast cancer in men: a case report and review of the literatüre. Tumori 2007;93:225-7.

5. Kahla PB, Cassaro S, Vlandimir FG, et al. Bilateral synchronous breast cancer in a male. Mt Sinai J Med 2005;72:120-3.

6. Orea Estudillo D, Hernández Rubio A, García Rodríguez FM, et al. Cáncer de mama bilateral. Experiencia de 10 años en la unidad de Oncología del hospital Juárez de México Cirujano General 2007;29:283-88.

7. Sun $W Y$, Lee $K H$, Lee $H C$, et al. Synchronous bilateral male breast cancer: a case report. J Breast Cancer 2012;15:248-51.

8. González Ortega JM, Gómez Hernández MM, López Cuevas ZC, et al. Cáncer de mama bilateral. Estudio clínico-patológico de 30 años (España: Complejo Hospitalario de Ciudad Real) 2005.

9. Hoque HM, Kothari A, Hamed H, et al. Synchronous bilateral breast cancer in a patient with Klinefelter's syndrome. Int J Gen Med 2010;3:19-21.

10. Hirose $Y$, Sasa M, Bando $Y$, et al. Bilateral male breast cancer with male potential hypogonadism. World J Surg Oncol 2007;5:60.

11. Qureshi K, Athwal R, Cropp G, et al. Bilateral Synchronous Ductal Carcinoma in Situ in a Young Man: Case Report and Review of The Literature. Clin Breast Cancer 2007;7:710-2.

12. Burga A, Fadare O, Lininger RA, et al. Invasive Carcinoma of The Male Breast: A Morphologic Study of The Distribution of Histologic Subtypes and Metastatic Patterns in 778 Cases. Virchows Arch 2006;449:507-12.

13. Gómez RC, Zambrana F, Serreno M, et al. Male Breast Cancer. Cancer Treat Rev 2010;36:451-7.

14. Weiss JR, Moysich KB, Swede H. Epidemiology of Male Breast Cancer. Cancer Epidemiol Biomarkers Prev 2005;14:20-6.

15. Gómez-Pérez R, Osuna JA, Arata-Bellabarba G. Surgical vs. Untreated Cryptorchidism: Effects on Fertility. Arch Androl 2004;50 19-22.

16. Giordano SH. Are View of The Diagnosis and Management of Male Breast Cancer. Oncologist 2005;10:471-9.

17. Bloom KJ, Govil H, Gattuso P, et al. Status of HER-2 in Male and Female Breast Carcinoma. Am J Surg 2001;182:389-92.

18. PDQ [website] USA (2012) National Cancer Institute [updated 13 Jan 2012; referenced25Jan2013] Retrieved from http:// www.cancer.gov/cancertopics/types/breast 